\title{
ANALISIS PEMANFAATAN KOLEKSI JURNAL INTERNASIONAL TERCETAK: TINJAUAN KEBIJAKAN PENGEMBANGAN KOLEKSI JURNAL ONLINE DI PDII-LIPI
}

\author{
Wahid Nashihuddin*, Tupan*
}

Pengutipan: Nashihuddin. W, \& Tupan, T. (2019). Analisis pemanfaatan koleksi jurnal internasional tercetak: tinjauan kebijakan pengembangan koleksi jurnal online di PDII-LIPI. Khizanah al-Hikmah : Jurnal Ilmu Perpustakaan, Informasi, dan Kearsipan, 7(1), 38-55. DOI: 10.24252/kah.v7i1a4.

*Pusat Dokumentasi dan Informasi Ilmiah - Lembaga Ilmu Pengetahuan Indonesia Email: wahed87@gmail.com

(Submitted: 01-02-2019, Revised: 14-03-2019, Accepted: 15-03-2019)

\begin{abstract}
ABSTRAK: Tujuan dari penelitian ini adalah: (1) mengetahui pemanfaatan jurnal internasional tercetak yang dilanggan oleh PDII-LIPI pada tahun 1991-1998; (2) mengetahui ketersediaan artikel sebelumnya (back issue) di jurnal cetak internasional di database online; (3) menjelaskan strategi dalam mengembangkan koleksi jurnal dengan berlangganan basis data jurnal. Metode penelitian ini menggunakan data kualitatif dengan pendekatan evaluatif, yang bersumber dari studi literatur dan pengambilan informasi jurnal dalam database online. Sampel data penelitian terdiri dari 21 jurnal dari 1601 jurnal yang dilanggan oleh PDII-LIPI pada 1991-1998. Hasil studi menunjukkan bahwa: (1) tren pemanfaatan jurnal cetak internasional dari setiap tahun telah menurun secara signifikan (data terbaru pada 2012); dari 2013 hingga sekarang, layanan jurnal ini tidak diaktifkan lagi karena itu bukan layanan prioritas di perpustakaan PDII-LIPI; (2) sebagian besar artikel sebelumnya di jurnal cetak internasional memiliki artikel lengkap dalam database online, seperti ScienceDirect, SpringerLink, JStor, ProQuest, basis data jurnal dilanggan oleh Kemenristek-Dikti dan Perpustakaan Nasional Indonesia, dan database jurnal akses terbuka; (3) PDII-LIPI perlu menetapkan kebijakan manajemen koleksi terutama jurnal online melalui konsorsium.
\end{abstract}

Kata kunci: Jurnal; manajemen koleksi; pengadaan koleksi; layanan perpustakaan

\section{ANALYSIS OF THE USAGE OF PRINTED INTERNATIONAL JOURNAL COLLECTIONS: OVERVIEW OF ONLINE JOURNAL COLLECTION COLLECTION POLICY IN PDII-LIPI}

\begin{abstract}
The purposes of this study are to; (1) find out the utilization of printed international journals subscribed by PDII-LIPI in 1991-1998; (2) know the availability of previous articles (back issue) in the international printed journals in the online databases; (3) explain the strategies of developing journal collections by subscribing of the journal databases. The method of this study used the qualitative data with evaluatif approach that sourced from the literature study and the journal information retrieval in online databases. The samples of the research data consist of 21 journals from 1601 journals that were subscribed by PDII-LIPI in 1991-1998. The study results indicated that: (1) the utilization trend of the international printed journal from each year has decreased significantly (the latest data in 2012); from 2013 until now, this journal service had not activated again because it was not a priority service in the PDII-LIPI library; (2) most of the previous articles in the international printed journals have full articles in online databases, such as ScienceDirect, SpringerLink, JStor, ProQuest, journal databases were subscribed by Ministry of Research, Technology, and Higher Education and National Library of Indonesia, and open access journal databases; (3) PDII-LIPI needs to set the policies of collection management especially on online journals through consortium.
\end{abstract}

Keywords: Journal; collection management; collection acquisition; library service 


\section{PENDAHULUAN}

Era digital membawa perubahan dan perilaku pengguna dalam mengakses sumber-sumber informasi perpustakaan, salah satunya terlihat pada akses jurnal online atau jurnal elektronik (e-journal). Hal tersebut terlihat juga di Pusat Dokumentasi dan Informasi Ilmiah-Lembaga Ilmu Pengetahuan Indonesia (PDII-LIPI) bahwa terjadi penurunan akses artikel jurnal dalam bentuk tercetak dan terjadi peningkatan permintaan akses artikel jurnal online, baik jurnal Indonesia maupun jurnal luar negeri/internasional yang dilanggan. Meningkatnya pengakses jurnal online ke PDII-LIPI disebabkan pengguna atau pemohon informasi jurnal ingin mendapatkan artikel jurnal yang mudah, cepat, dan murah. Sementara untuk mendapatkan jurnal tercetak, ia harus datang ke perpustakaan dan memfotokopi yang dianggap kurang efektif dan efisien. Terkait permintaan layanan jurnal online ini, PDII-LIPI menyediakan layanan penelusuran informasi jurnal melalui email dan form permintaan layanan penelusuran informasi online.

Adanya peningkatan permintaan artikel jurnal dan pemesanan jurnal secara online berdampak pada menurunnya pemanfaatan jurnal tercetak di PDII-LIPI, khususnya akses terhadap "majalah catu" atau jurnal internasional yang dilanggan oleh lembaga. Sebelum melanggan Jurnal Internasional, sejak tahun 1966, Pusat Dokumentasi Ilmiah Nasional/PDIN (sebelum berganti nama menjadi PDII) telah aktif menyediakan layanan informasi kilat dengan cara mengirimkan daftar isi majalah yang dilanggan oleh LIPI, termasuk layanan percetakan dan penggandaan dokumen. Bahkan pada tahun 1980 layanan jurnal Internasional ini diperluas lagi dengan menawarkan berbagai judul melalui info kilat yang berisi daftar isi majalah dan jurnal Internasional, baik yang dilanggan LIPI maupun usulan dari pihak luar. Gray (1972) setelah melakukan kunjungan ke Perpustakaan LIPI yang ada di Jakarta, Bogor, dan Bandung menemukan masalah terhadap kurangnya ketersediaan dan akses jurnal Internasional bagi peneliti di lingkungan LIPI. Untuk itu, selain melalui pembelian jurnal Internasional, PDIN disarankan juga aktif melakukan kerjasama dan pertukaran bahan pustaka ke luar negeri, dengan cara demikian kebutuhan penelitian terhadap akses jurnal Internasional akan terpenuhi (Bachtar, 2005).

Terjadinya penurunan akses jurnal Internasional dan tidak tersedianya database untuk mengakses artikel ke jurnal tersebut, menyebabkan lembaga harus memikirkan kebijakan pengembangan koleksi jurnal yang sesuai dengan kebutuhan informasi dan perilaku pengguna jasa PDII-LIPI. Terlihat bahwa pemanfaatan jurnal Internasional di PDII-LIPI hanya sampai tahun 2011 dan setelahnya koleksi tersebut sudah tidak lagi dimanfaatkan oleh pengguna. Terkait dengan pemanfaatan jurnal tercetak di perpustakaan, Nur'aini (2015) mengatakan bahwa responden merasa kesulitan dalam memanfaatkan jurnal tercetak sebanyak 19 responden $(22,6 \%)$ menyatakan selalu, 43 responden $(51,1 \%)$ menyatakan sering, 13 responden $(15,4 \%)$ menyatakan kadang-kadang dan 9 responden $(10,7 \%)$ menyatakan tidak pernah.

Berdasarkan pertimbangan tersebut, sejak tahun 2013, PDII-LIPI melakukan penataan koleksi jurnal Internasional tercetak untuk bahan evaluasi pengembangan koleksi jurnal Internasional versi online. Misalnya PDII-LIPI bekerjasama dengan Kementerian Riste, Teknologi, dan Pendidikan Tinggi (Kemenristekdikti) melanggan database ScienceDirect (tahun 2012) dan melanggan database SpringerLink dan Scopus (2013).

Dalam proses pengembangan koleksi jurnal Internasional online, PDII-LIPI terlebih dahulu melakukan penataan koleksi (stock opname) dan melakukan evaluasi pemanfataan koleksi sebagai dasar penyiangan koleksi (weeding) terhadap koleksi jurnal Internasional tercetak di perpustakaan (tahun 2018). Dasar pelaksanaan penyiangan koleksi ini adalah ditemukannya sebagian besar artikel full text jurnal Internasional tercetak pada database jurnal online, baik yang dilanggan oleh PDII-LIPI, Kemenristekdikti, Perpustakaan Nasional Republik Indonesia, maupun database jurnal open access. Berdasarkan hal tersebut, kajian ini membahas tiga hal, yaitu: (1) bagaimana pemanfaatan jurnal internasional tercetak yang dilanggan oleh PDII-LIPI pada tahun 2004-2012?; (2) bagaimana ketersediaan artikel sebelumnya (back issue) di jurnal 
cetak internasional di database online?; (3) menjelaskan upaya dalam mengembangkan koleksi jurnal dengan berlangganan basis data jurnal?.

\section{KAJIAN TERDAHULU/TINJAUAN PUSTAKA}

\section{Jurnal}

Di lembaga perpustakaan, majalah dan jurnal masuk kategori koleksi terbitan berkala (serial/periodical). Menurut Reitz (2014), jurnal adalah sebuah berkala yang didedikasikan untuk menyebarkan hasil-hasil penelitian asli dan komentar tentang perkembangan saat ini dalam berbagai disiplin ilmu tertentu, sub-disiplin, atau bidang lain yang lebih spesifik (misalnya: Journal of Clinical Epidemiology). Jurnal biasanya diterbitkan secara berkala, baik triwulanan, dua bulanan, atau semesteran, atau tahunan. Artikel jurnal biasanya ditulis oleh orang yang telah melakukan penelitian. Dalam menulis artikel jurnal, penulis diminta untuk menyertakan sumber referensi yang menjadi bahan kutipan dan daftar pustaka. Hal yang sama dikatakan Nur'aini (2015), bahwa jurnal merupakan salah satu koleksi perpustakaan yang dibutuhkan oleh pengguna untuk menemukan informasi tentang penemuan ilmiah terkini. Dalam hal pengelompokkan koleksi perpustakaan, pada dasarnya jurnal termasuk ke dalam kategori koleksi serial.

Menurut Peraturan Menteri Riset, Teknologi, dan Pendidikan Tinggi RI Nomor 9 Tahun 2018 Tentang Akreditasi Jurnal Ilmiah (Kemenristekdikti, 2018), jurnal ilmiah adalah bentuk pemberitaan atau komunikasi yang memuat karya ilmiah dan diterbitkan berjadwal dalam bentuk elektronik dan/atau tercetak. Menurut peraturan tersebut, jurnal berfungsi sebagai: (a) register, meregistrasi kegiatan kecendekiaan; (b) arsip, mengarsipkan temuan hasil kegiatan kecendekiaan ilmuan; (c) pengakuan, mengakui hasil kegiatan yang memenuhi persyaratan ilmiah; (d) diseminasi, mendiseminasikan hasil kegiatan kecendekiaan dan hasil pengabdian kepada masyarakat; dan (f) perlindungan, melindungi hasil karya peneliti/cendekiawan. Suatu terbitan disebut sebagai terbitan jurnal ilmiah online, jika minimal memenuhi syarat:

1) memuat artikel yang secara nyata memajukan ilmu pengetahuan, teknologi, dan/atau seni yang didasarkan pada hasil penelitian, perekayasaan, dan/atau telaahan yang mengandung temuan dan/atau pemikiran yang orisinil serta tidak plagiat;

2) memiliki dewan penyunting jurnal berkualifikasi sesuai dengan bidang ilmu yang mewakili bidang ilmu pengetahuan, teknologi, dan/atau seni;

3) melibatkan mitra bestari berkualifikasi sesuai dengan bidang ilmu jurnal dari berbagai perguruan tinggi dan/atau badan penelitian dan pengembangan serta industri yang berbeda dari dalam dan/atau luar negeri yang menyaring naskah secara objektif;

4) menggunakan Bahasa Indonesia dan/atau bahasa resmi Perserikatan Bangsa-Bangsa;

5) menjaga konsistensi gaya penulisan dan format penampilan;

6) terbit sesuai dengan jadwal;

7) dikelola dan diterbitkan secara elektronik melalui jejaring teknologi informasi dan komunikasi;

8) memiliki nomor seri standar internasional secara elektronik (Electronic International Standard Serial Number/EISSN) dan pengenal objek digital (Digital Object Identifier/DOI).

\section{Versi Jurnal}

Secara umum jurnal yang dikelola perpustakaan dapat disediakan dalam tiga versi atau bentuk, yaitu jurnal tercetak (printed journal), jurnal daring (online journal) atau jurnal elektronik (electronic journal). Menurut Molingka, Dewi, \& Damayanty (2014) jurnal tercetak merupakan suatu terbitan berseri dalam bentuk cetak yang mencakup kumpulan pengetahuan baru, pengalaman empiris, dan pengembangan gagasan dalam suatu bidang ilmu pengetahuan dan teknologi, serta diterbitkan oleh lembaga penerbitan akademik, masyarakat pembelajar dan organisasi profesi.

Pemanfaatan koleksi jurnal tercetak dalam memenuhi kebutuhan informasi merupakan sebuah perilaku nyata yang dapat dilihat di perpustakaan. E-journal menurut Reitz (2014), 
adalah versi digital dari jurnal cetak, atau publikasi melalui proses elektronik. E-journal ini dapat diakses melalui web, email, atau cara lain melalui internet. Sathe et al (2002) mengatakan e-journal merupakan koleksi integral di perpustakaan. Dalam pengembangan koleksi e-journal, biasanya ada masalah akademik yang sesuai dengan kebutuhan bidang studi di perpustakaan. Perpustakaan mengakui dalam melanggan e-journal, perlu menyiapkan desain layanan e-journal yang efektif agar pemanfaatannya dapat dievaluasi secara berkala.

Sedangkan jurnal online adalah sarana berbasis web untuk mengelola sebuah jurnal. Jurnal online atau jurnal dalam format elektronik merupakan salah satu alternatif yang dapat dimanfaatkan oleh pengelola jurnal. Selain faktor efektifitas pengelolaan dan manajemen jurnal, sebagian besar platform jurnal online juga bersifat open source dan gratis. Salah satu platform jurnal online yang banyak digunakan dan cukup andal adalah Open Journal System/OJS (Arief \& Handoko, 2017).

Murniati (2012) membedakan e-journal menjadi dua, yaitu: (1) e-journal yang dapat diakses tanpa biaya dan dapat dicetak atau bebas download; dan (2) e-journal yang dapat diakes dengan cara berbayar, seperti JSTOR, Springerlink, ScienceDirect, dan Scopus. Tresnawan (2005) dalam Nur'aini (2015) menjelaskan perbedaan jurnal tercetak dan jurnal elektronik.

Tabel 1. Perbedaan Jurnal Tercetak dan Jurnal Online

\begin{tabular}{|c|c|c|c|}
\hline No & Aspek & Jurnal Cetak & Jurnal Online \\
\hline 1 & Format & Lembar lepas & File digital (pdf/dsb.) \\
\hline 2 & Kecepatan diterima & Lambat & Cepat \\
\hline 3 & Penyimpanan & $\begin{array}{l}\text { Rak koleksi (tempat yang } \\
\text { luas) }\end{array}$ & $\begin{array}{l}\text { Web/database (menghemat } \\
\text { tempat) }\end{array}$ \\
\hline 4 & Pemanfaatan & Terbatas jam buka layanan & $24 \mathrm{Jam}$ \\
\hline 5 & Kesempatan akses & Antri (harus datang) & Bisa bersamaan (online) \\
\hline 6 & Penelusuran & Harus dibuat/memesan & Otomatis tersedia \\
\hline 7 & Waktu penelusuran & Lama & Cepat \\
\hline 8 & Keamanan & Kurang aman & Lebih aman \\
\hline 9 & Manipulasi dokumen & Tidak bisa & Sangat mudah \\
\hline 10 & $\begin{array}{l}\text { Langganan dengan harga } \\
\text { yang sama }\end{array}$ & Judul lebih sedikit & Judul bisa lebih banyak \\
\hline 11 & Harga langganan & $\begin{array}{l}\text { lebih mahal (ada pajak } \\
\text { pengiriman) }\end{array}$ & lebih murah \\
\hline 12 & $\begin{array}{l}\text { Rekam jejak Editor \& } \\
\text { reviewer }\end{array}$ & Tidak informatif & $\begin{array}{l}\text { Informatif (ada link karya } \\
\text { tulis/publikasi) }\end{array}$ \\
\hline
\end{tabular}

Persamaan jurnal tercetak dan jurnal online/e-journal adalah sama-sama melalui tahap review dan editorial, serta memiliki isi artikel, tampilan layout text, dan identitas jurnal yang sama. Sedangkan perbedaannya adalah media review dan editorial serta diseminasi jurnal. Jurnal tercetak, media review dan editorial melalui naskah yang dicetak kemudian dikirim viapos atau faximile ke reviewer \& editor, jika melalui email, file dipindai (scan) atau sudah dalam bentuk PDF (kemudian dicetak sendiri oleh reviewer/editor). Sedangkan jurnal online/ejournal, media review dan editorialnya melalui jaringan internet, baik melalui email, melalui aplikasi e-journal (misalnya OJS - Open Journal System), maupun kombinasi antara keduanya (email dan melalui OJS), sehingga rekam jejak editorial dan review dapat ditelusuri history-nya.

\section{Pengembangan Koleksi Jurnal di PDII-LIPI}

Menurut Buku Pedoman Kerja Perpustakaan PDIN-LIPI, pengadaan majalah luar negeri melalui; (a) langganan (pembelian), bersumber dari anggaran rutin LIPI dan anggaran pembangunan koleksi PDIN melalui Meulen-hoff-Bruna BV Amsterdam-Belanda, dengan mengirim surat, dengan mengusulkan daftar majalah ilmiah luar negeri yang dilanggan untuk tahun yang akan datang. Daftar majalah yang dilanggan bersumber dari Ebsco Librarian's Handbook atau invoice majalah yang pernah dilanggan sebelumnya; (b) hadiah atau tukar menukar, yang bersumber dari biro publikasi LIPI "Indonesian Abstracs" dan PDIN-LIPI "Indeks 
Majalah Ilmiah (Index of Indonesian Learned Periodicals)", serta "Laporan Tahunan (Annual Report) PDIN". Selain itu, PDIN-LIPI juga menerima majalah LN dari sumbangan badan lembaga internasional di Indonesia, seperti UNESCO, British Council, Kedutaan Besar Belanda dan Amerika, Asia Foundation, dan lembaga perwakilan Asia lainnya (PDIN, 1980).

Jurnal Internasional ini dilanggan PDII-LIPI selama delapan tahun dari tahun 1991-1998 melalui Proyek Sistem Informasi Proyek Nasional bersumber dari APBN. Dalam kurun waktu tersebut, PDII-LIPI telah melanggan sejumlah 1610 judul. Jurnal Internasional ini tidak hanya dilayankan di Perpustakaan PDII-LIPI di Jakarta, tetapi juga dikirim dan dilayankan di Puslitbang LIPI yang ada di Bogor, Cibinong, Serpong, Bandung, dan Ambon. Jurnal yang dilanggan kemudian diolah dan disusun menggunakan Dewey Decimal Classification (DDC) dan Library of Congress Subject Headings (LCSH). Sistem layanan jurnal Internasional belum menggunakan database perpustakaan tetapi menggunakan "Buku Daftar Majalah Ilmiah Luar Negeri yang Dilanggan PDII-LIPI”. Pencarian artikel berdasarkan pencarian judul, subjek, dan indeks artikel jurnal (Marzuki \& Kohar, 1998).

Permadi (2015) mengatakan bahwa kebijakan pengembangan koleksi di PDII-LIPI seperti bahan sumbangan, petunjuk pertukaran terbitan, dan penyiangan bahan menjadi pilihan dan cara yang efisien untuk pemilihan koleksi yang akan dikelola dan dilayankan ke pengguna. Dalam pengembangan koleksi, PDII-LIPI harus memperhatikan asas: (1) koleksi harus menyediakan informasi untuk kegiatan penelitian dan kegiatan ilmiah yang dilakukan oleh LIPI; (2) koleksi harus mendukung penelitian dan pendidikan tinggi di Indonesia dalam bidang kompetensi LIPI; (3) koleksi harus menyediakan akses jangka panjang ke informasi iptek dari Indonesia; (4) koleksi harus menjadi karya ilmiah nasional dalam bidang kompetensi LIPI; dan (5) koleksi tidak menimbulkan duplikasi dengan koleksi yang dikelola lembaga lain. Kebijakan pengembangan koleksi majalah internasional, yang pada umumnya tersedia di pangkalan data dan dapat diakses melalui internet, perlu dipertimbangkan lagi jika ingin berlangganan majalah internasional versi cetak. Karena majalah elektronik yang dilanggan kemungkinan berisi seluruh isi versi cetak.

\section{Kajian Pemanfaatan Jurnal di Perpustakaan}

Lamothe (2012) melaporkan hasil analisis kuantitatif tentang faktor-faktor yang mempengaruhi penggunaan e-journal di J.N. Desmarais Perpustakaan Universitas Laurentian. Penelitian dilakukan selama 11 tahun dari tahun 2000-2010. Penelitian tersebut untuk mengetahui jumlah artikel lengkap yang di-download dibandingkan dengan jumlah ketersediaan e-journal; jumlah mahasiswa dan jumlah anggota dari fakultas yang ada di universitas. Hasil penelitian menunjukkan bahwa semuanya memberikan pengaruh pada tingkat penggunaan ejournal. Koefisien korelasi momen produk Pearson dihitung untuk menentukan kekuatan hubungan linier yang ada. Meskipun ukuran koleksi e-journal telah mempengaruhi tingkat penggunaannya, namun ada "masa kritis", yang pernah dicapai, hal tersebut dapat memperlambat atau menghentikan peningkatan penggunaan e-journal lebih lanjut. Dilihat dari populasi penelitian, terlihat bahwa jumlah mahasiswa doktor menunjukkan hubungan linier terkuat yang memanfaatkan e-journal yang disediakan oleh perpustakaan. Sedangkan anggota fakultas tidak memiliki hubungan linier yang sekuat dalam mengakses informasi e-journal sebagaimana yang dilakukan oleh mahasiswa pascasarjana di Universitas Laurentian. Terkait hal tersebut, mahasiswa pascasarjana perlu memberikan masukan terhadap sistem pengadaan koleksi dan manajemen e-journal untuk meningkatkan minat anggota fakultas untuk mengakses e-journal yang tersedia di perpustakaan.

Tenopir et. al (2009) berusaha meneliti bagaimana anggota fakultas ilmu pengetahuan, teknologi, kedokteran dan ilmu sosial memperoleh, membaca dan menggunakan artikel ilmiah, dan bagaimana perubahannya dengan tersedianya jurnal dan jurnal alternatif. Hasil penelitian menunjukkan bahwa rata-rata jumlah pembaca per tahun per anggota fakultas sains terus meningkat. Moghaddam \& Talawar (2008) mengkaji penggunaan jurnal ilmiah di Institut Ilmu Pengetahuan India (IISc). Hasilnya menunjukkan minat yang meningkat terhadap penggunaan ejournal di IISc. Dokumen dalam format PDF merupakan format yang paling disukai pengguna 
dan konten e-journal dapat diakses melalui komputer mereka sendiri. Dapat dikatakan bahwa lembaga lebih memilih langganan e-journal dari pada langganan jurnal tercetak. Kusmayadi (2008) mengatakan dari hasil kajian akses dan pemanfaatan pangkalan data jurnal ilmiah diketahui bahwa sumber informasi digital yang dilanggan berdampak pada permintaan informasi mereka yang semakin meningkat karena dapat menunjang tugas mereka, menghemat waktu dan biaya, dan pemanfaatannya mudah dipahami oleh para peneliti. Pengguna e-journal mengambil artikel lengkap dalam bentuk page image atau file PDF selain membaca abstrak dan informasi bibliografisnya.

\section{METODOLOGI PENELITIAN}

Jenis data kajian ini adalah kualitatif, dengan pendekatan evaluatif. Evaluasi merupakan salah satu penerapan dari penelitian yang berguna untuk menentukan berhasil atau tidaknya atau apakah ada manfaat/nilai dari suatu program atau kebijakan dalam pendidikan (McMillan \& Schumacher, 2010). Penelitian evaluatif bertujuan untuk mengumpulkan informasi tentang kondisi nyata mengenai keterlaksanaan rencana yang memerlukan evaluasi (Sejathi, 2011).

Pada kajian ini, peneliti akan mengevaluasi pokok permasalahan berdasarkan studi literatur atau dokumen, baik yang bersumber dari artikel dan laporan pemanfaatan koleksi Jurnal Internasional tercetak Perpustakaan PDII-LIPI, maupun data penelusuran informasi artikel back issue Jurnal Internasional tercetak pada database jurnal online, baik yang dilanggan oleh PDIILIPI, Kemenristekdikti, Perpustakan Nasional Republik Indoneisa, maupun melalui database jurnal open access. Data yang digunakan untuk mengevaluasi pemanfaatan jurnal internasional tercetak adalah data tahun 2004-2012. Penelusuran informasi artikel jurnal Internasional di database jurnal menggunakan kata kunci "nama jurnal" dan "judul artikel".

Berdasarkan data jurnal Internasional tercetak yang dilanggan PDII-LIPI tahun 1991-1998 diketahui ada sejumlah populasi 1601 judul jurnal (Tabel 1), jumlah tersebut merupakan populasi penelitian ini. Dari jumlah populasi jurnal tersebut kemudian peneliti mengambil 21 sampel jurnal untuk dijadikan bahan penelusuran artikel back issue jurnal pada database jurnal online. Jurnal Internasional tercetak yang dijadikan sampel ialah sebagai berikut:

1) Analytical Sciences (ISSN 0910- 6340);

2) Applied Entomology and Zoology (ISSN 0003-6862);

3) Bioscience, Biotechnology, and Biochemistry (ISSN 0916-8451);

4) Journal of Biochemistry (ISSN 0021-924X);

5) Journal of Electron Microscopy (ISSN 0022-0744);

6) Radioisotopes (ISSN 0033-8303);

7) Waste Management (ISSN 0956-053X);

8) AIChE Journal (ISSN 0001-1541);

9) American Journal of Physics (ISSN 0002-9505);

10) Applied and Environmental Microbiology (ISSN 0099-2240);

11) Applied Solar Energy (ISSN 0003-701X);

12) Biochemical Medicine and Metabolic Biology (ISSN 0885-4505);

13) Biomedical Instrumentation and Technology (ISSN 0899-8205);

14) Biophysical Journal (ISSN 0006-3495);

15) Biotechnology and Bioengineering (ISSN 0006-3592);

16) Bryologist (ISSN 0007-2745);

17) Bulletin of Marine Science (ISSN 0007-4977);

18) Photogrammetric Engineering Remote Sensing (ISSN 0099-1112);

19) Analytica Chimica Acta (ISSN 0003-2670);

20) Aquatic Botany (ISSN 0304-3770);

21) International Journal of Coal Geology (ISSN 0166-5162).

Data yang terkumpul kemudian dijabarkan secara deskriptif dengan pendekatan studi literatur dan hasil pengamatan peneliti. 


\section{HASIL DAN PEMBAHASAN}

\section{Pemanfaatan Jurnal Internasional Tercetak PDII-LIPI}

Berdasarkan data statistik pemakaian jurnal Internasional tercetak di Perpustakaan PDIILIPI diketahui bahwa koleksi ini dipakai terakhir tahun 2012, sedangkan data pemakaian terbitan tahun 2013-2018 tidak ada. Dalam kurun waktu tersebut terlihat bahwa tren pemanfaatan jurnal Internasional tercetak yang dilanggan PDII-LIPI jumlahnya menurun. Hal tersebut terlihat dari data pengguna yang memanfaatkan koleksi jurnal Internasional tercetak tahun 2004-2012 (Tabel 1 dan Grafik 1).

Tabel 1. Jumlah Pengguna Jurnal Internasional Tercetak Langganan PDII-LIPI

\begin{tabular}{cc}
\hline Tahun & Jumlah Pengguna (Orang) \\
\hline 2004 & 67056 \\
2005 & 63098 \\
$\mathbf{2 0 0 6}$ & $\mathbf{7 5 1 7 4}$ \\
2007 & 1325 \\
2008 & 989 \\
2009 & 237 \\
2010 & 222 \\
2011 & 179 \\
2012 & 158 \\
\hline Total & $\mathbf{2 0 8 4 3 8}$ \\
\hline
\end{tabular}

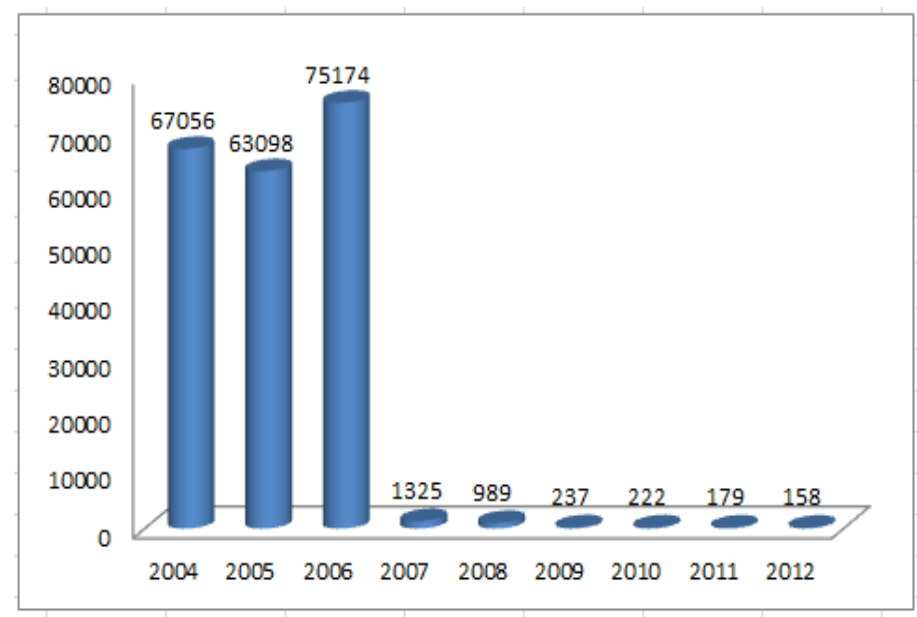

Grafik 1. Statistik Pemanfaatan Jurnal Internasional Tercetak

Ada beberapa alasan adanya penurunan pemakaian jurnal internasional tercetak yang dilanggan oleh PDII-LIPI, antara lain; (a) keterbatasan kemampuan bahasa Inggris pengguna dalam mencari nama jurnal dan judul artikel yang terkandung dalam Jurnal Internasional tercetak yang dilanggan oleh PDII-LIPI; pengguna lebih memilih mencari jurnal nasional yang berbahasa Indonesia karena isinya mudah dipahami; (b) sebagian besar artikel Jurnal Internasional tercetak dapat diakses secara online dan full text melalui database jurnal internasional yang dilanggan oleh PDII-LIPI dan database jurnal open access. Kemudian tidak adanya data pemanfaatan Jurnal Internasional tercetak di perpustakaan PDII-LIPI sejak tahun 2013 hingga sekarang disebabkan beberapa hal, diantaranya:

1) Adanya kebijakan pimpinan lembaga terkait kegiatan migrasi database Jurnal Internasional tercetak dari sistem WinISIS ke sistem Indonesian Scientific Journal Database (ISJD), di mana di ISJD hanya khusus database jurnal ilmiah Indonesia-sehingga Jurnal Internasional tercetak tidak dapat diakses lagi secara online oleh pengguna. Alasan migrasi database ISJD karena PDII-LIPI ingin fokus pada pengelolaan jurnal ilmah Indonesia, dan lembaga akan 
melanggan database jurnal internasional, seperti ScienceDirect (https://www.sciencedirect.com/), SpringerLink (https://link.springer.com/), JStor (https://www.jstor.org/), ProQuest (https://search.proquest.com/asfa/). Langganan database Jurnal Internasional dianggap lebih memudahkan pengguna untuk mendapatkan informasi hasil-hasil penelitian secara mudah, cepat, dan mutakhir. Beberapa link database Jurnal Internasional yang dilanggan PDII-LIPI dapat diakses melalui jaringan IntraLIPI (https://intra2.lipi.go.id/) sebagaimana ditampilkan pada Gambar 1.

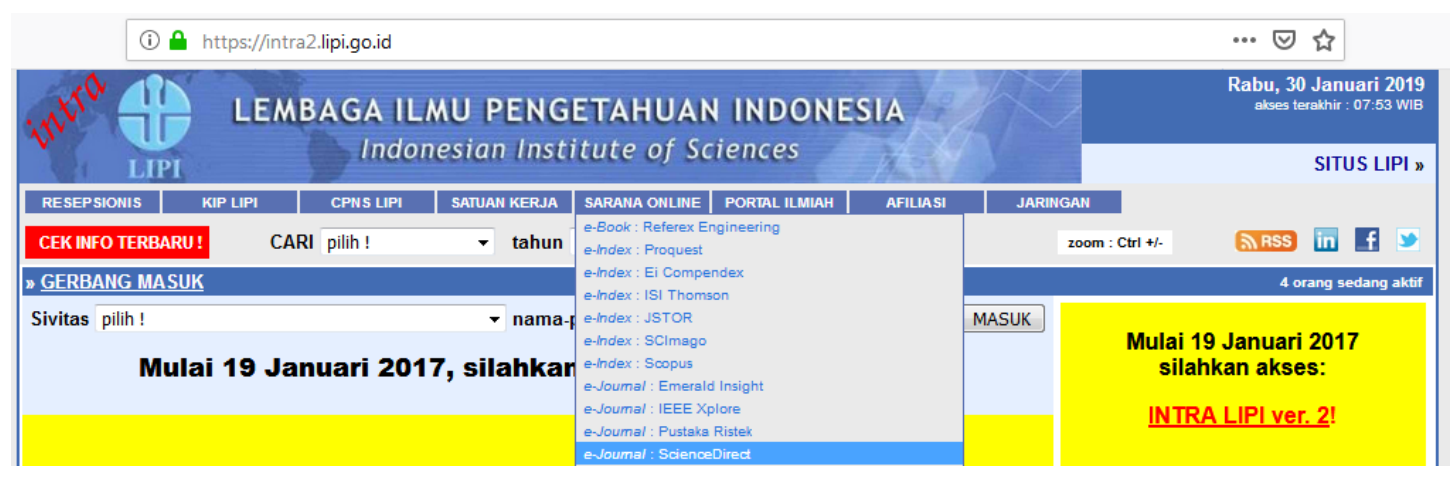

Gambar 1. Portal Jaringan IntraLIPI Akses Database Jurnal Internasional Langganan PDII-LIPI

2) Kebijakan manajemen koleksi pada tahun 2018 terkait rencana lembaga untuk mengurangi koleksi layanan perpustakaan bentuk tercetak (termasuk jurnal internasional tercetak) dan alih fungsi perpustakaan sebagai co-working space. Menurut Bilandzic \& Foth (2013), suatu perpustakaan yang berfungsi sebagai co-working space setidaknya harus: (a) menyediakan perangkat komputer, Wifi, peralatan multimedia, dan aplikasi-aplikasi berbayar; (b) menyediakan ruangan untuk individu dan group; dan (c) fasilitas untuk menyelenggarakan workshop, presentasi, pameran dan berbagai kegiatan ilmiah lainnya.

Penurunan jumlah pemakaian jurnal tercetak di perpustakaan juga dapat disebabkan karena kurang praktis dan cepat dalam mengakses informasi full text jurnal, khususnya pada saat mencari koleksi di rak perpustakaan dan dapat juga disebabkan karena petunjuk lokasi koleksi jurnal tercetak kurang jelas.

\section{Ketersediaan Artikel Edisi Lalu Jurnal Internasional}

Berdasarkan data jurnal Internasional tercetak yang dilanggan oleh PDII-LIPI tahun 19911998 diketahui ada 1610 judul (Tabel 2). Berdasarkan tabel dan gambar terlihat bahwa jurnal Internasional tercetak yang dilanggan paling banyak oleh PDII-LIPI adalah jurnal bidang ilmu teknologi (722 judul) dan yang paling sedikit adalah bidang ilmu bahasa dan karya sastra, internasional 1 judul. Hal tersebut disebabkan karena bidang ilmu karya sastra, bahasa, serta ilmu agama dan kesenian, kurang relevan dan kurang mendukung langsung kebutuhan informasi peneliti di lingkungan LIPI. Adapun fokus bidang penelitian di LIPI antara lain penelitian Ilmu Pengetahuan Sosial dan Kemanusiaan (IPSK), Ilmu Pengetahuan Hayati (IPH), Ilmu Pengetahuan Teknik (IPT), dan Ilmu Pengetahuan Kebumian (IPK), dan informasi tersebut dapat dilihat dari Website LIPI di http://lipi.go.id/\#kedeputian.

Tabel 2. Jumlah Jurnal Internasional Tercetak yang Dilanggan PDII-LIPI

\begin{tabular}{|c|c|c|}
\hline No & Bidang Ilmu & Jumlah Judul \\
\hline 1 & Umum & 182 \\
\hline 2 & Filsafat & 9 \\
\hline
\end{tabular}




\begin{tabular}{clc} 
& Psikologi & \\
3 & Agama & 3 \\
4 & Sosial & 302 \\
5 & Bahasa & 1 \\
6 & Alam & 334 \\
7 & Teknologi & 722 \\
8 & Kesenian & 3 \\
9 & Karya Sastra & 1 \\
10 & Sejarah & 53 \\
& Geografi & \\
\hline & Total & \\
\hline
\end{tabular}

Berdasarkan data jumlah pengguna (Tabel 1) dan data jumlah judul jurnal Internasional tercetak (Tabel 2) yang dilanggan lembaga terlihat bahwa PDII-LIPI sudah melanggan jurnal Internasional tercetak sesuai kebutuhan informasi peneliti di LIPI pada waktu itu. Namun sejak tahun 2013 yang tidak ada data pemanfaatannya, lembaga perlu mengevaluasi kembali apakah keberadaan jurnal tersebut masih perlu dilayankan ke pengguna atau tidak - mengingat database untuk akses jurnal Internasional tercetak tidak dapat diakses secara online ataupun lebih memilih berlangganan database jurnal Internasional yang berisi jurnal Internasional back issue tercetak.

Untuk mengetahui ketersediaan jurnal Internasional tercetak yang dilanggan, peneliti melakukan pengecekan dan penelusuran di database jurnal Internasional secara online, baik database jurnal Internasional yang dilanggan PDII-LIPI maupun database jurnal open access. Misalnya peneliti melakukan penelusuran jurnal dan artikel full text jurnal di:

1) Database jurnal Internasional berlangganan (baik LIPI, Kemenristekdikti, dan Perpustakaan Nasional RI), seperti jurnal bidang filsafat dan psikologi, ilmu sosial, ilmu alam, teknologi, sejarah dan geografi (http://link.springer.com/); bidang sosial dan kemanusian (https://www.jstor.org); bidang multidisiplin (https://www.scopus.com/, https://www.sciencedirect.com/; http://e-resources.perpusnas.go.id/).

2) Database jurnal Internasional open access, seperti jurnal bidang kimia (http://abcchemistry.org/index.html); bidang kesehatan (http://www.bmj.com/archive); bidang biologi (http://www.e-journals.org/botany/); bidang multidisiplin (http://www.freefullpdf.com, https://doaj.org/ $\quad$ http://academic.resea rch.amicrosoft.com/).

Berdasarkan hasil penelusuran pada database di atas diketahui bahwa sebagian besar naskah/artikel back issue jurnal Internasional tercetak langganan PDII-LIPI sudah tersedia dan dapat diakses secara full text dan online. Berikut ini bukti hasil penelusuran informasi naskah/artikel back issue dari jurnal Internasional yang dilanggan oleh PDII-LIPI.

- Analytical Sciences, artikel fulletxt jurnal ini dapat diakses secara gratis sejak tahun 1985 (Gambar 2).

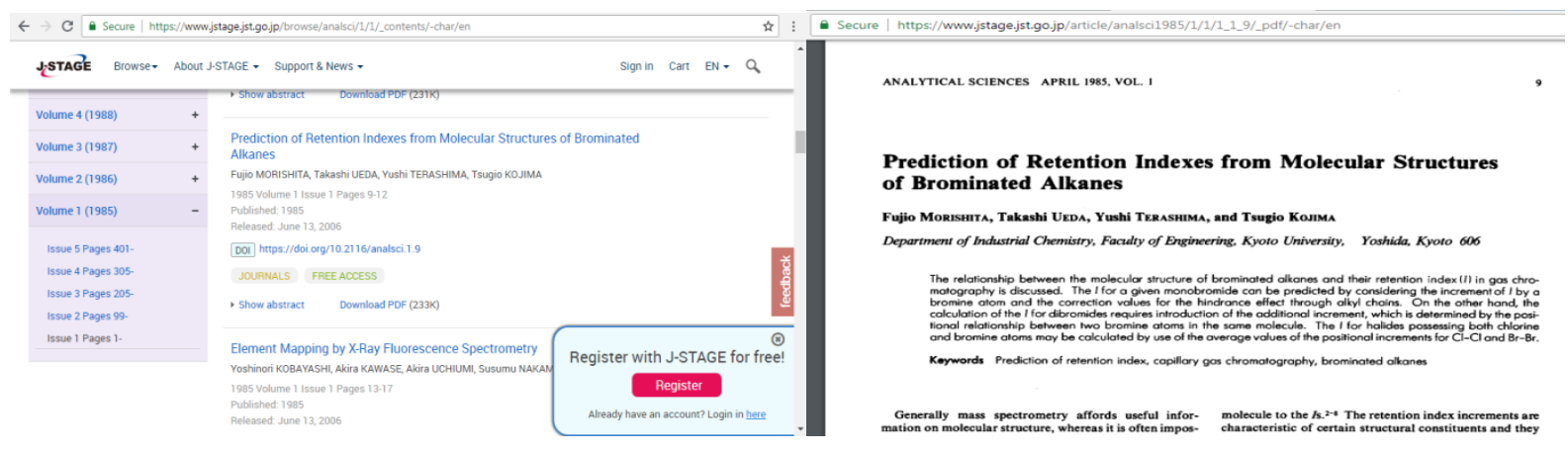

Gambar 2. Database dan Artikel Full text Jurnal "Analytical Sciences” 
- Applied Entomology and Zoology, artikel fulletxt jurnal ini dapat diakses secara gratis sejak tahun 1966 dan sejak tahun 2011 konten jurnal ini dapat diakses melalui database SpringerLink yang dilanggan oleh PDII-LIPI (Gambar 3).

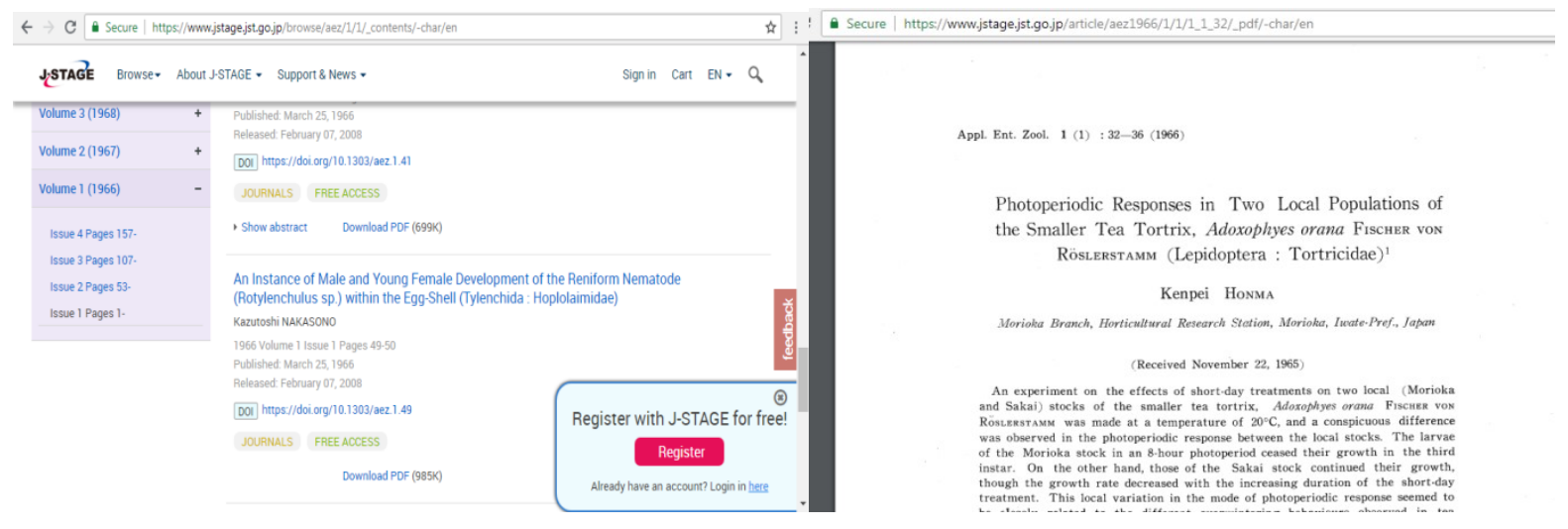

Gambar 3. Database dan Artikel Full text Jurnal "Applied Entomology and Zoology”

- Bioscience, Biotechnology, and Biochemistry, artikel full text jurnal ini dapat diakses secara gratis sejak tahun 1992, dimulai dari Volume 56 No.1-12, yang sesuai dengan daftar jurnal Internasional tercetak yang dilanggan oleh PDII-LIPI (Gambar 4).

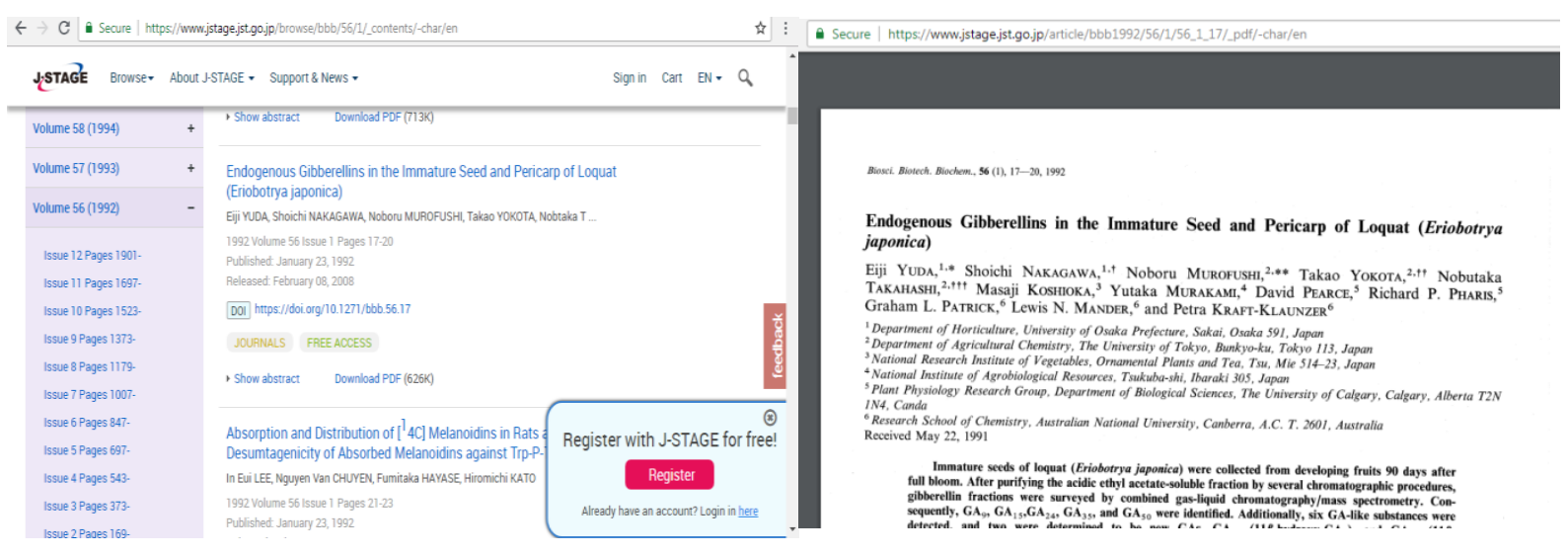

Gambar 4. Database dan Artikel Full text Jurnal “Bioscience, Biotechnology, and Biochemistry”

- Journal of Biochemistry, artikel full text jurnal ini dapat diakses secara gratis sejak tahun 1922 dan PDII-LIPI mulai langganan tahun 1991 (Gambar 5).

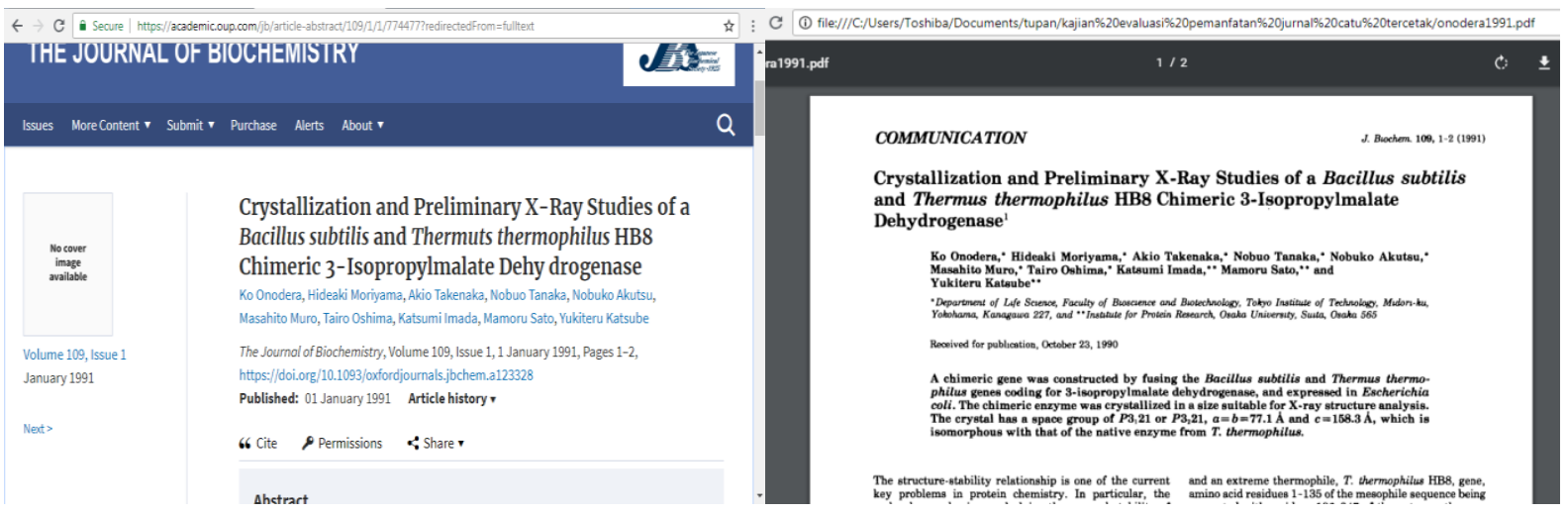

Gambar 5. Database dan Artikel Full text "Journal of Biochemistry" 
- Journal of Electron Microscopy, konten jurnal ini dapat diakses secara online sejak tahun 1984 dan PDII-LIPI melanggan jurnal ini sejak tahun 1991. Hal tersebut dibuktikan dengan hasil penelusuran berikut ini (Gambar 6).

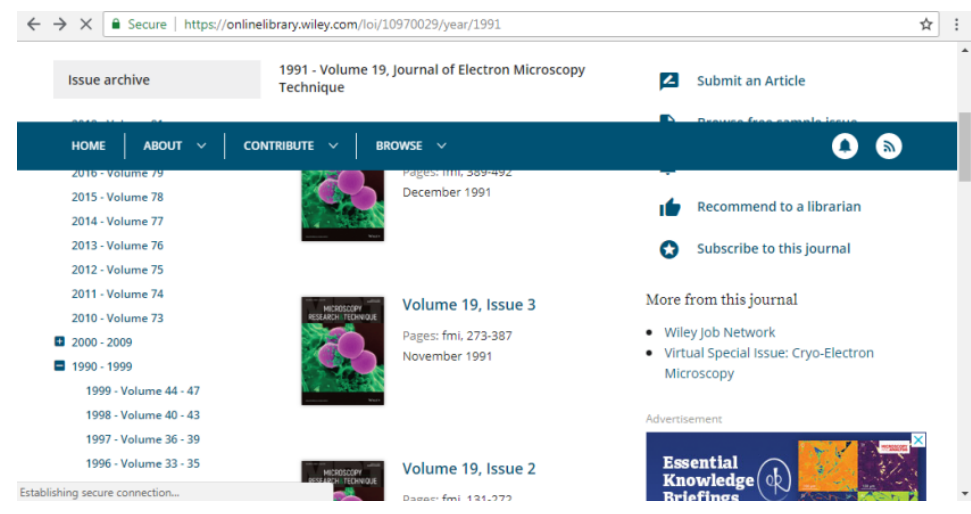

Gambar 6. Database "Journal of Electron Microscopy"

- Radioisotopes, artikel full text jurnal ini dapat diakses secara online dari Volume 1 Tahun 1952 dan PDII-LIPI mulai melanggan jurnal ini sejak tahun 1991 mulai Volume 40 Nomor 1-12, konten jurnal ini dapat diakses secara gratis (Gambar 7).

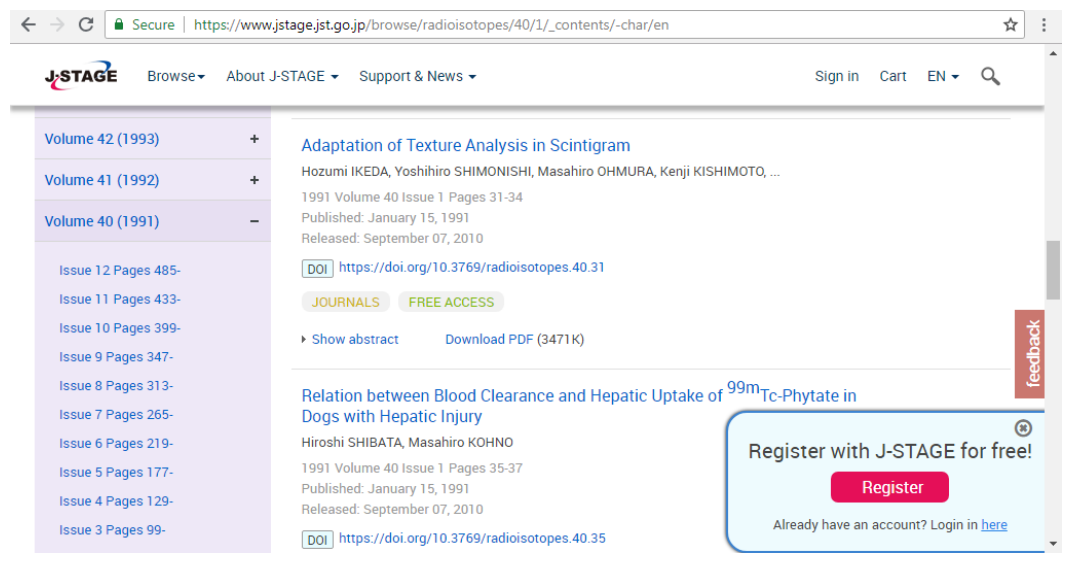

Gambar 7. Database Jurnal “Radioisotopes”

- Waste Management, artikel full text jurnal ini dapat diakses secara online sejak tahun 1989, mulai Volume 9 Nomor 1-4 dan PDII-LIPI melanggan jurnal ini sejak tahun 1993 (Gambar 8).

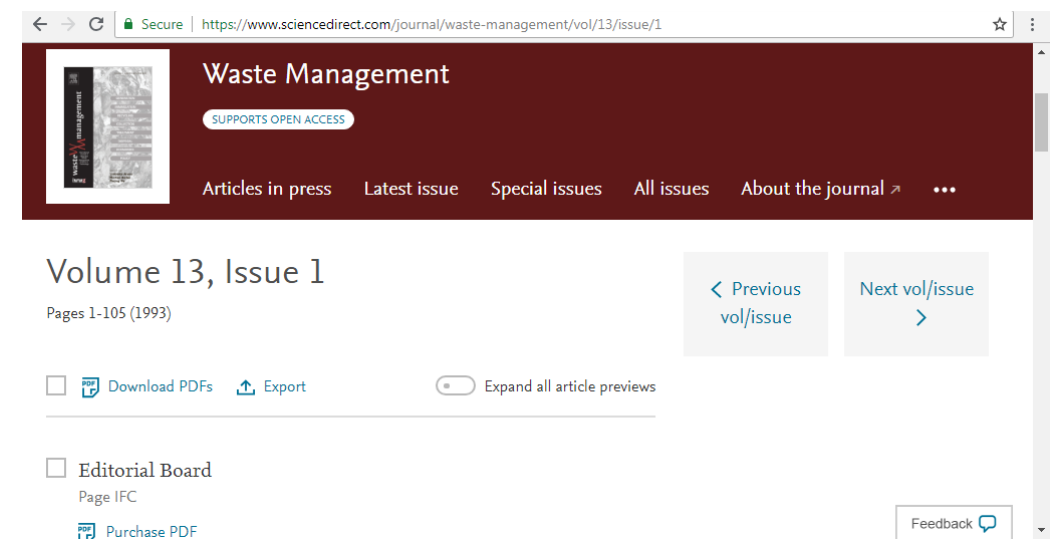

Gambar 8. Database Jurnal “Waste Management” 
- AIChE Journal, artikel full text jurnal ini dapat diakses secara online sejak tahun 1955 dan PDII-LIPI mulai melanggan jurnal ini sejak tahun 1991. Jurnal ini dapat diakses dengan cara melanggan (Gambar 9).

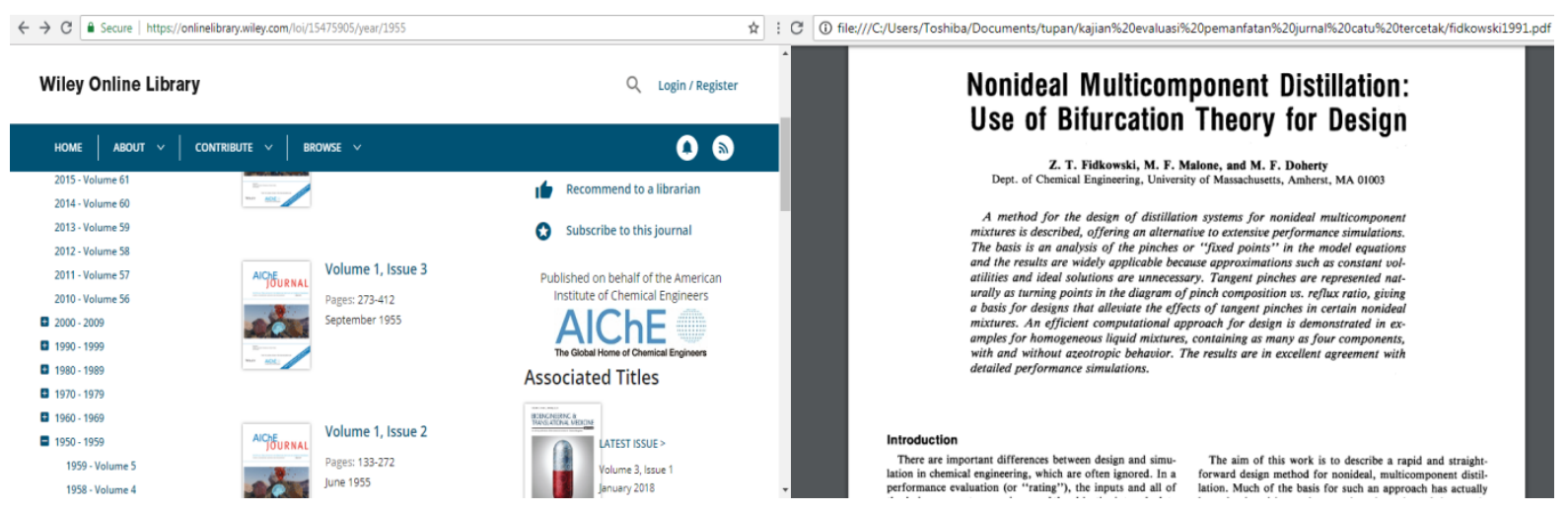

Gambar 9. Database dan Artikel Full text "AIChE Journal"

- American Journal of Physics, artikel full text konten jurnal ini dapat diakses secara online sejak tahun 1933, tepatnya Volume 1 dan PDII-LIPI mulai melanggan jurnal ini sejak tahun 1991. Jurnal ini dapat diakses dengan cara berbayar atau langganan (Gambar 10).

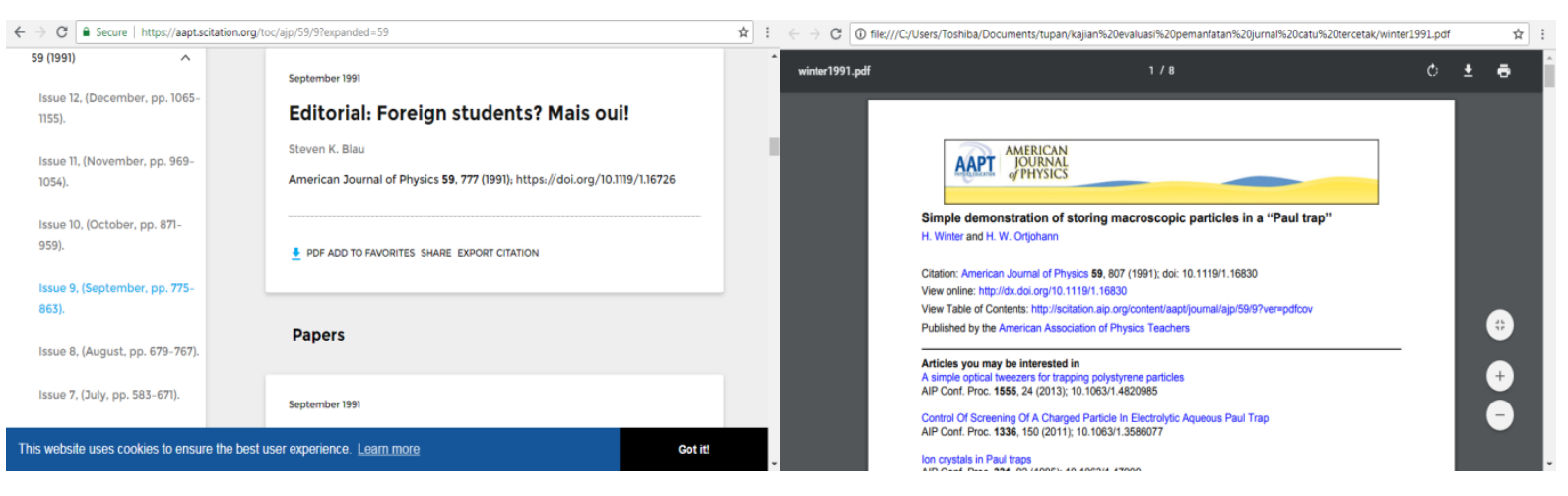

Gambar 10. Database dan Artikel Full text "American Journal of Physics"

- Applied and Environmental Microbiology, artikel full text jurnal ini dapat diakses secara online dan gratis sejak tahun 1953 dan PDII-LIPI mulai melanggan jurnal ini sejak tahun 1991 (Gambar 11).
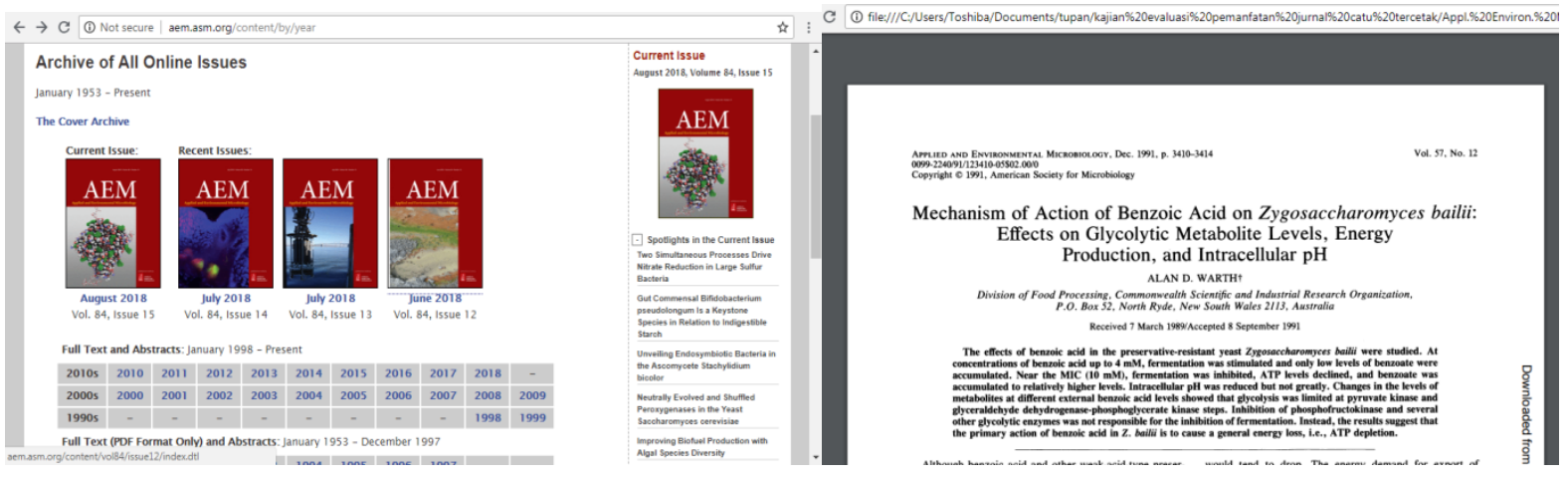

Gambar 11. Database dan Artikel Full text Jurnal "Applied and Environmental Microbiology" 
- Applied Solar Energy, artikel full text jurnal ini dapat diakses secara online sejak tahun 1977 dengan cara berbayar dan PDII-LIPI mulai melanggan jurnalnya sejak tahun 1991. Sejak tahun 2007 jurnal ini dapat diakses melalui database SpringerLink yang dilangan PDII-LIPI (Gambar 12).

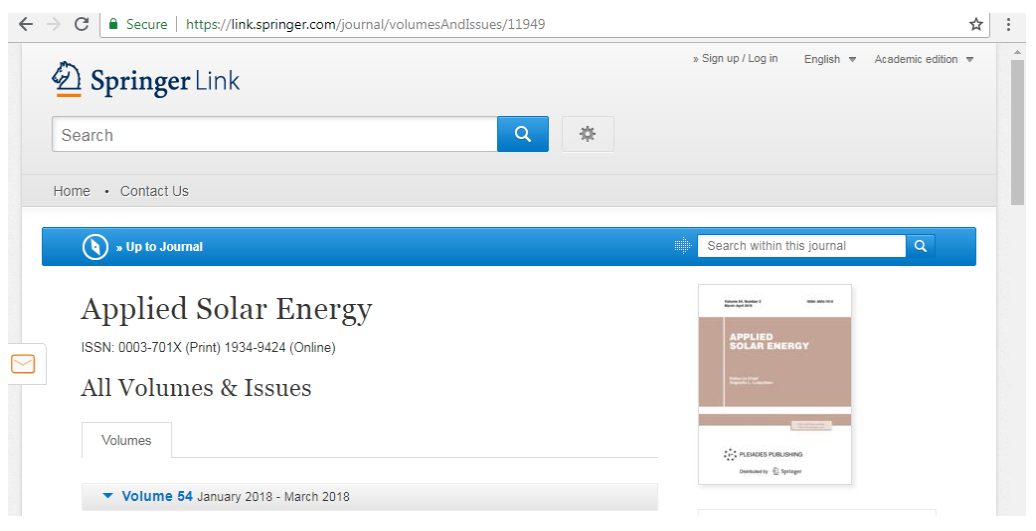

Gambar 12. Database Jurnal "Applied Solar Energy”

- Biochemical Medicine and Metabolic Biology, artikel full text jurnal ini dapat diakses secara online sejak tahun 1986, mulai Volume 35 Nomor 1 dan PDII-LIPI mulai melanggannya sejak tahun 1991. Jurnal ini dapat diakses melalui database ScienceDirect yang dilanggan oleh Kemenristekdikti (Gambar 13).

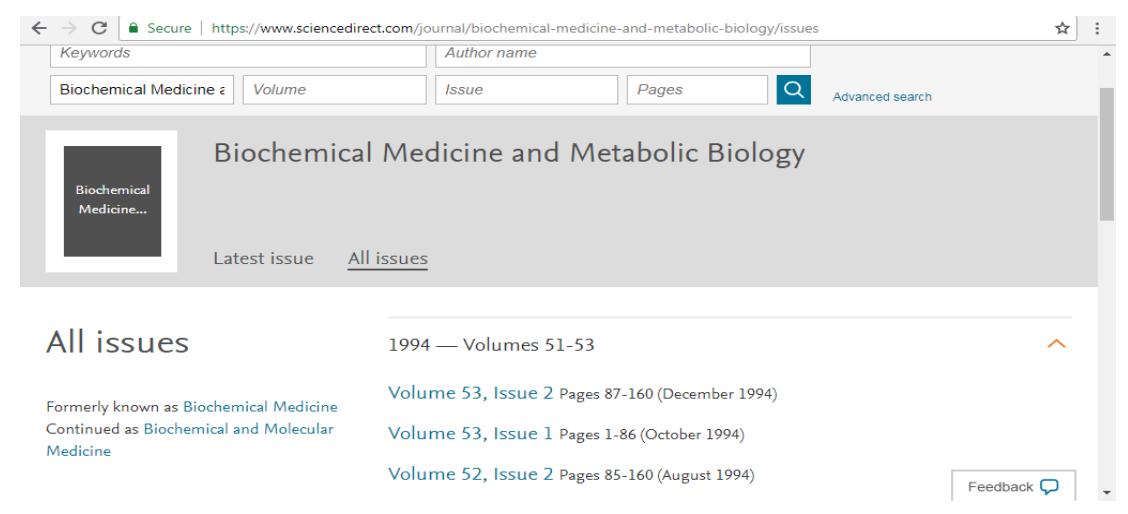

Gambar 13. Database Jurnal "Biochemical Medicine and Metabolic Biology”

- Biomedical Instrumentation and Technology, artikel full text jurnal ini dapat diakses secara online sejak tahun 1989 dan PDII-LIPI mulai melanggannya sejak tahun 1991. Artikel full text jurnal ini dapat diakses dengan cara berbayar (Gambar 14).

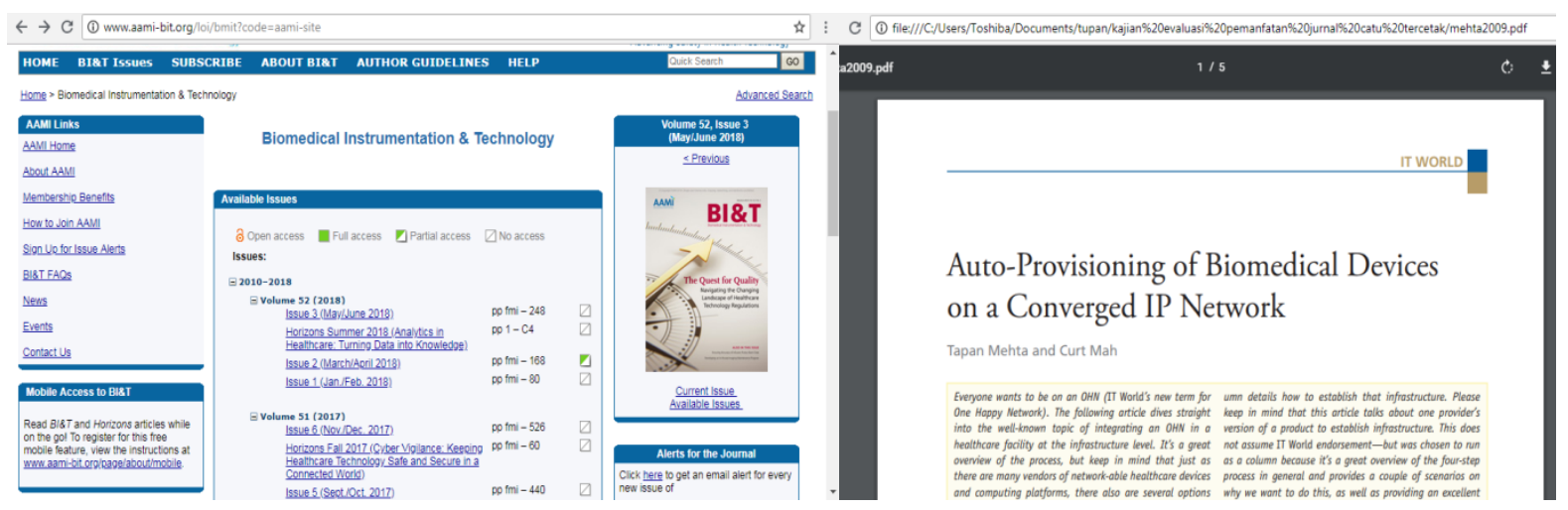

Gambar 14. Database dan Artikel Full text Jurnal "Biomedical Instrumentation and Technology" 
- Biophysical Journal, artikel full text konten jurnal ini dapat diakses secara online sejak tahun 1960, mulai Volume 1 dan PDII-LIPI melanggan jurnal ini sejak tahun 1991. Jurnal ini ada yang dapat diakses secara gratis dan berbayar. Jurnal ini dapat diakses secara gratis melalui database langganan jurnal PDII-LIPI sejak tahun 1991-1997 (Gambar 15).

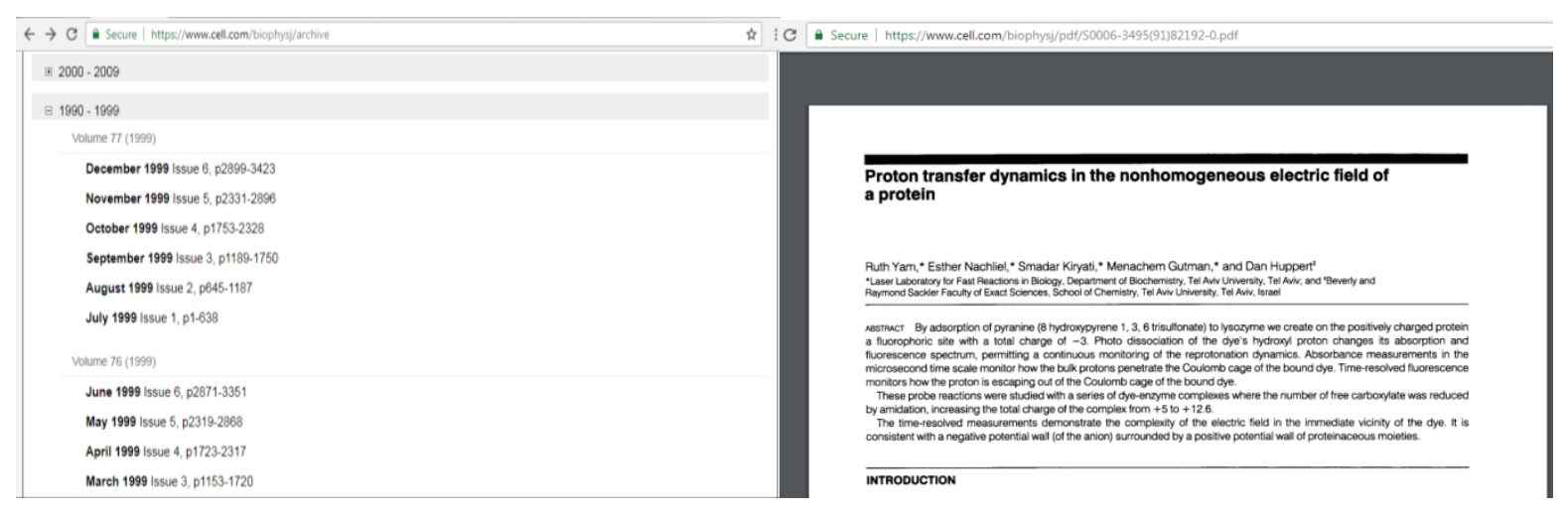

Gambar 15. Database dan Artikel Full text "Biophysical Journal"

- Biotechnology and Bioengineering, artikel full text jurnal ini dapat diakses secara online sejak tahun 1959 dan PDII-LIPI mulai melanggannya sejak tahun 1991-2001. Jurnal ini dapat diakses secara berbayar (Gambar 16).

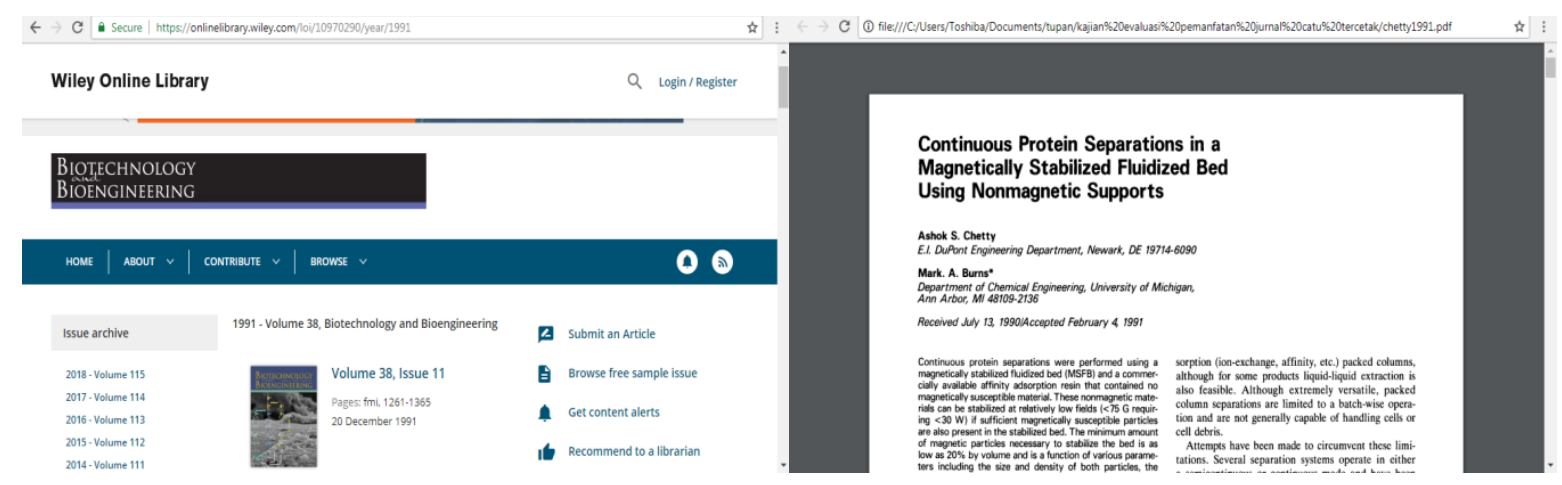

Gambar 16. Database dan Artikel Full text Jurnal "Biotechnology and Bioengineering”

- Bryologist, artikel full text jurnal ini dapat diakses secara online sejak tahun 1981 dan PDII-LIPI melanggannya sejak tahun 1991-1997. Jurnal ini dapat diakses secara berbayar dan dapat juga diakses melalui database JSTOR yang dilanggan oleh PDII-LIPI (Gambar 17).

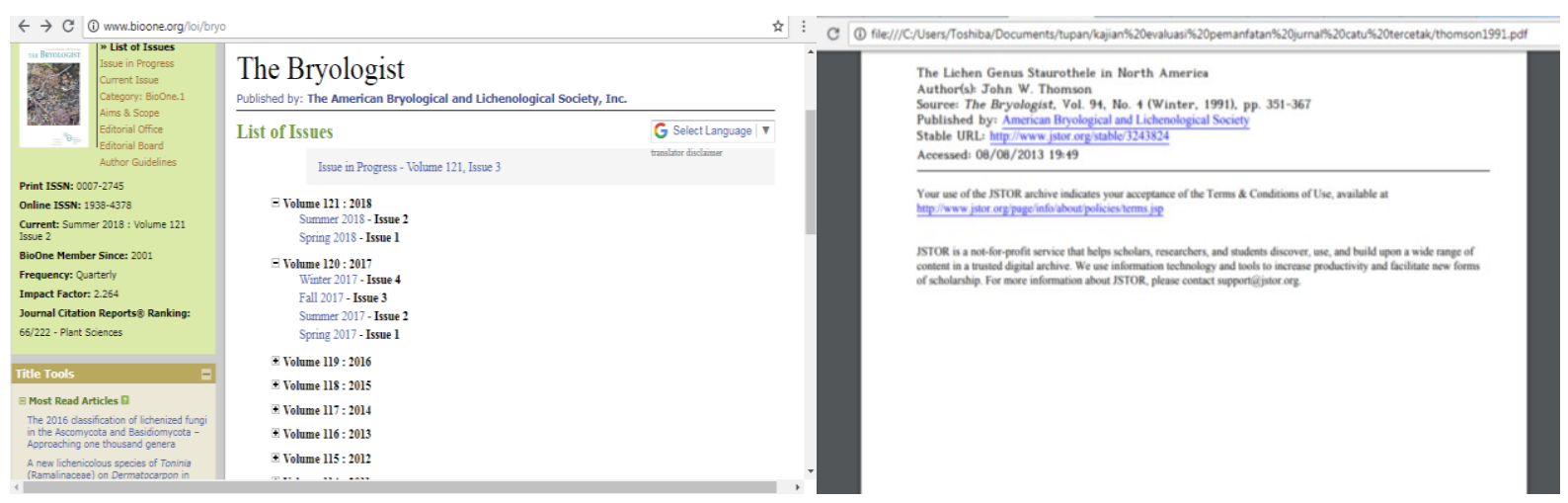

Gambar 17. Database dan Artikel Full text Jurnal "Bryologist" 
- Bulletin of Marine Science, artikel full text jurnal ini dapat diakses secara online sejak tahun 1951 dan PDII-LIPI melanggannya sejak tahun 1991-1997. Jurnal ini dapat diakses secara berbayar dan ada juga yang gratis (Gambar 18).

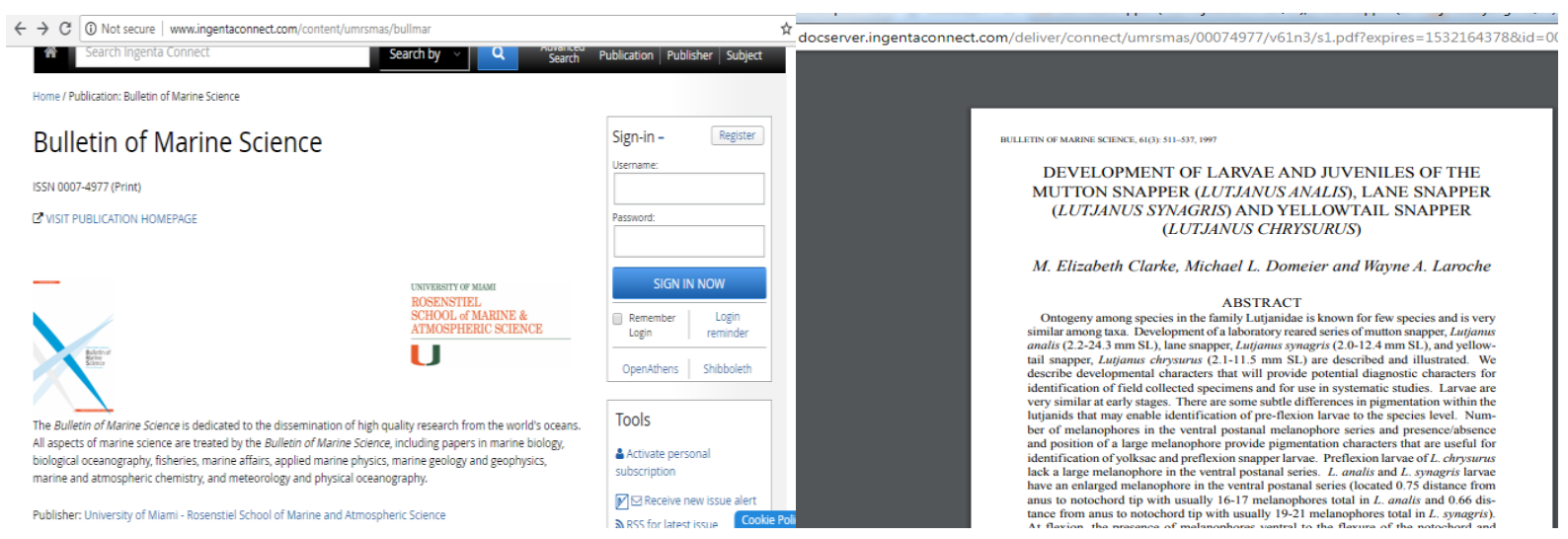

Gambar 18. Database dan Artikel Full text Jurnal "Bulletin of Marine Science"

- Photogrammetric Engineering Remote Sensing, artikel full text konten jurnal ini dapat diakses secara online sejak tahun 1975 dan PDII-LIPI melanggannya sejak tahun 1991-1997. Jurnal ini dapat diakses melalui database ScienceDirect dan Scopus yang dilanggan oleh Kemenristekdikti (Gambar 19).
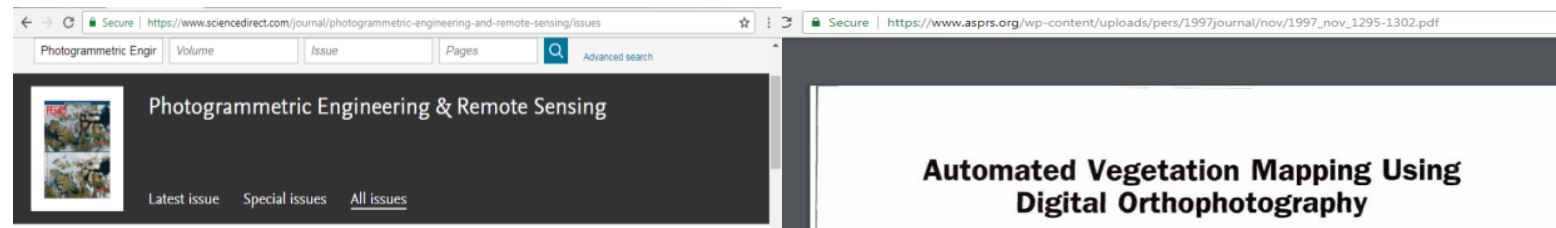

All issues
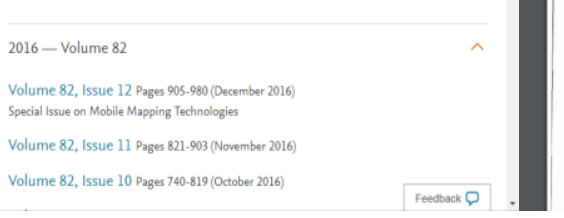

Automated Vegetation Mapping Using Digital Orthophotography

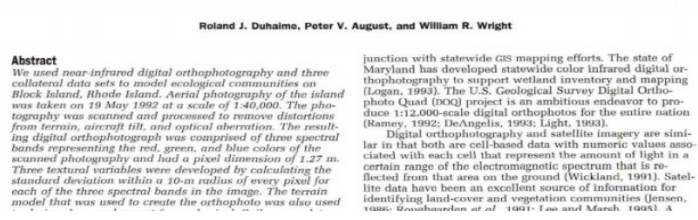

Gambar 19. Database dan Artikel Full text Jurnal "Photogrammetric Engineering Remote Sensing"

- Analytica Chimica Acta, artikel full text jurnal ini dapat diakses secara online sejak tahun 1947 dan PDII-LIPI hanya melanggan jurnal ini tahun 1990. Jurnal ini juga dapat diakses secara berlangganan melalui database ScienceDirect (Gambar 20).

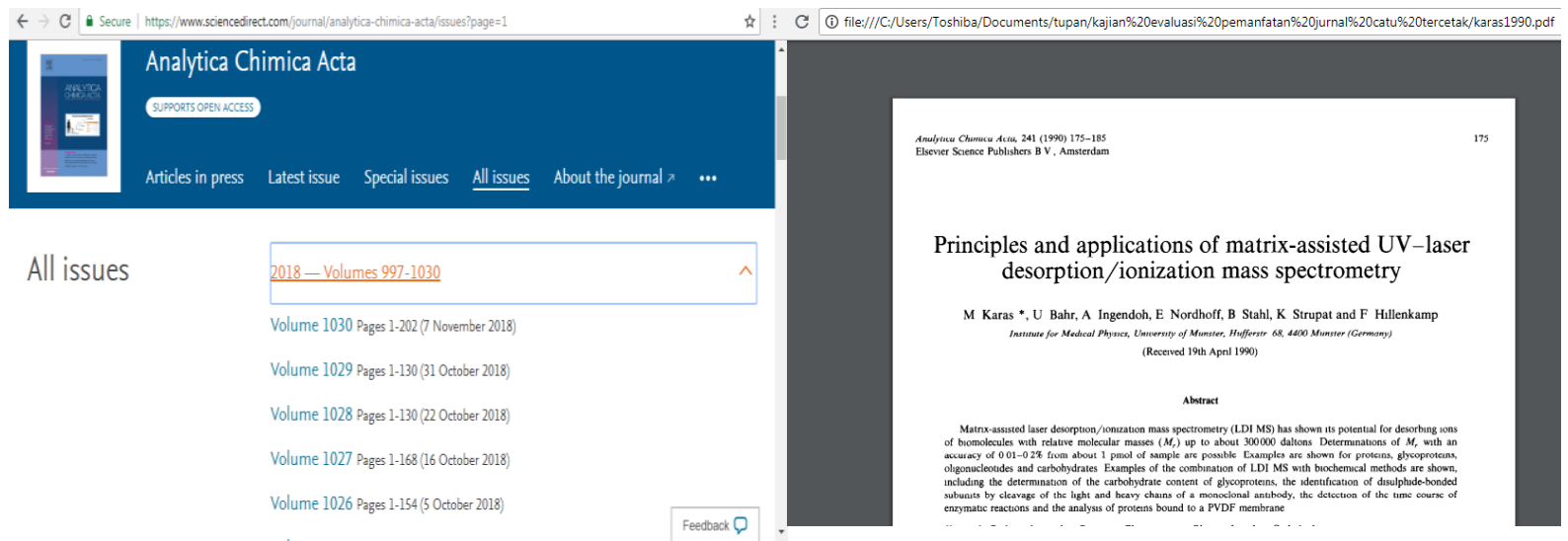

Gambar 20. Database dan Artikel Full text Jurnal "Analytica Chimica Acta” 
- Aquatic Botany, artikel full text jurnal ini dapat diakses secara online sejak tahun 1975 dan PDII-LIPI hanya melanggan jurnal ini tahun 1991. Jurnal ini dapat diakses secara berbayar melalui database ScienceDirect yang dilanggan oleh Kemenristek-Dikti (Gambar 21).

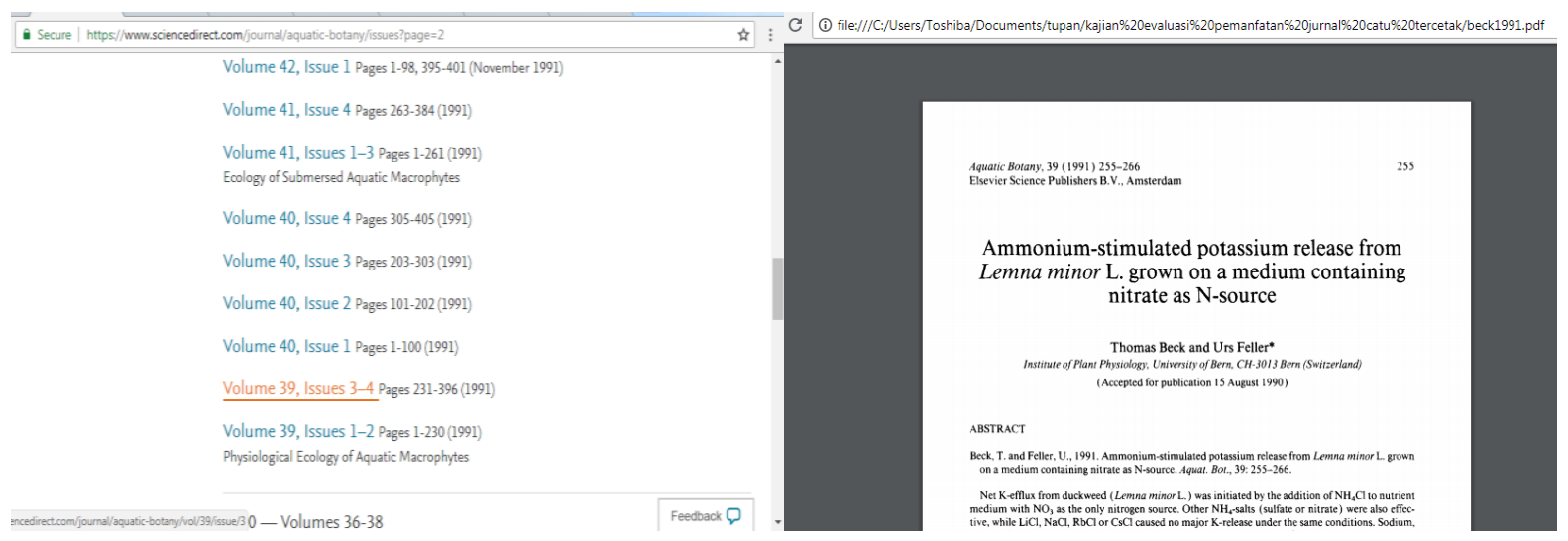

Gambar 21. Database dan Artikel Full text Jurnal "Aquatic Botany”

- International Journal of Coal Geology, artikel full text jurnal ini dapat diakses secara online sejak tahun 1980 dan PDII-LIPI melanggannya sejak tahun 1991-1996. Jurnal ini dapat diakses melalui database ScienceDirect yang dilanggan oleh Kemenristek-Dikti (Gambar 22).
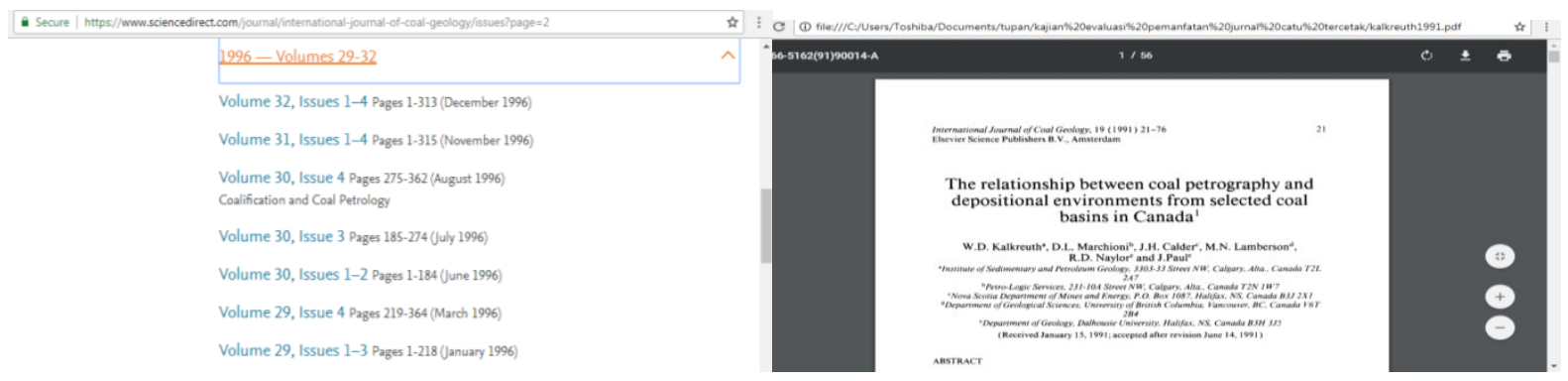

Gambar 22. Database dan Artikel Full text Jurnal "International Journal of Coal Geology"

\section{Strategi Pengembangan Koleksi Jurnal Online}

Berdasarkan uraian pembahasan di atas dapat dikatakan bahwa sebagian besar jurnal dan artikel jurnal Internasional tercetak yang dilanggan oleh PDII-LIPI sudah tersedia di beberapa database yang dilanggan oleh PDII-LIPI, Kemenristekdikti, dan Perpustakaan Nasional RI. Meskipun belum semua jurnal dicek dan ditelusur di database jurnal Internasional yang dilanggan lembaga, dapat terlihat bahwa naskah/artikel back issue jurnal tercetak sudah ada di database jurnal online.

Apabila PDII-LIPI akan mengelola kembali jurnal Internasional versi tercetak perlu mempertimbangkan beberapa aspek, di antaranya: (1) kebijakan manajemen koleksi; (2) ketersediaan tempat atau lokasi rak koleksi layanan; (3) kenyamanan ruang baca perpustakaan; (4) database/katalog akses koleksi; (5) kemutakhiran isi jurnal; (6) kemudahan dan kecepatan akses informasi jurnal; dan (7) perilaku pengguna digital native.

Jika masih dipertahankan untuk koleksi perpustakaan, perlu ada seleksi dan prioritas koleksi yang akan dipreservasi dan dilayankan kembali ke pengguna. Namun, jika tidak dipertahankan lagi sebagai koleksi perpustakaan, maka lembaga perlu menetapkan strategi dalam pengembangan koleksi jurnal online dengan cara berlangganan. O'doherty \& Boissy (2009) mengatakan bahwa jika lembaga memiliki keterbatasan anggaran untuk melanggan 
jurnal online, lembaga perlu melakukan "konsorsium" secara komprehensif. Melalui konsorsium, penerbit memberikan daftar semua jurnal (multidisplin ilmu) yang akan dilanggan berdasarkan kesepakatan bersama (antar-perpustakaan atau antar-lembaga) yang dibuktikan dengan berkas portofolio.

Ada beberapa aspek yang perlu diperhatikan dalam pengembangan jurnal online melalui kegiatan konsorsium, yaitu: (a) menyiapkan semua berkas portofolio atau daftar penerbit jurnal online/e-journal; (b) setiap peserta konsorsium mendapatkan hak untuk mengusulkan semua jurnal yang akan dilanggan, termasuk pengarsipannya; (c) penerbit dan peserta konsorsium menyetujui harga berkelanjutan per tahun sesuai kesepakatan; (d) masalah harga langganan jurnal harus dijelaskan secara komprehensif; (e) penerbit mengirimkan faktur penawaran sebagai bahan pertimbangan langganan oleh peserta konsorsium; (f) penetapan agen atau vendor ditetapkan kemudian setelah ada hasil negosiasi kesepakatan keduanya.

\section{KESIMPULAN}

Pemanfaatan jurnal tercetak perlu dievaluasi kembali untuk peningkatan mutu layanan perpustakaan yang lebih baik. Pimpinan perpustakaan/lembaga yang dibantu oleh pustakawan perlu segera merumuskan dan menetapkan kebijakan manajemen koleksi, khususnya dalam pengembangan koleksi jurnal yang akan dikelolanya, apakah akan tetap melayankan jurnal cetak atau jurnal online/e-journal. Hal tersebut tentunya disesuaikan dengan perilaku pengguna perpustakaan saat ini, di mana mereka lebih suka mengakses konten jurnal online dari pada jurnal tercetak. Termasuk di PDII-LIPI, pemanfaatan jurnal Internasional tercetak yang dilanggan PDII-LIPI tahun 1991-1998 juga harus dievaluasi, apakah informasinya masih mutakhir dan masih sering diakses oleh penggunanya.

Berdasarkan hasil dan pembahasan di atas diketahui bahwa tren pemakaian jurnal Internasional tercetak yang dilanggan PDII-LIPI jumlahnya semakin menurun hingga tahun 2012, termasuk terakhir pemanfaatannya juga pada tahun tersebut. Sedangkan sejak tahun 2013 sampai sekarang, jurnal Internasional tercetak ini sudah tidak ada lagi yang memanfaatkan, karena faktor kebijakan lembaga yang mungkin sudah tidak lagi memprioritaskan jurnal Internasional tercetak sebagai koleksi perpustakaan dan layanan unggulan lembaga. Kebijakan tersebut merupakan suatu hal yang wajar, karena PDII-LIPI lebih fokus pada pengembangan layanan jurnal ilmiah Indonesia yang dapat diakses melalui Indonesia Scientific Journal Database (ISJD) dan langganan database jurnal Internasional yang dapat diakses secara online, seperti ScienceDirect, SpringerLink, JStor, dan ProQuest; serta memanfaatkan database jurnal Internasional yang dilanggan oleh Kemenristekdikti dan Perpustakaan Nasional RI, dan database jurnal open access.

Dengan memanfaatkan berbagai database jurnal tersebut, diketahui bahwa sebagian besar naskah/artikel back issue atau edisi terdahulu jurnal Internasional tercetak yang dilanggan oleh PDII-LIPI sudah tersedia dan artikel full text-nya dapat diakses secara online dan sebagian ada yang gratis (berdasarkan hasil penelusuran informasi terhadap 21 sampel jurnal Internasional tercetak di database jurnal online).

Meskipun demikian, pimpinan PDII-LIPI perlu meninjau kembali kebijakan manajemen koleksi jurnal Internasional tercetak yang sudah dilanggan, sehingga pemanfaatannya lebih optimal. Sebagai saran, apabila ingin mengeluarkan koleksi tersebut karena dianggap sudah tidak mutakhir dan tersedia online, mungkin perlu memilih kembali koleksi jurnal tersebut yang dianggap relevan dengan tugas, pokok dan fungsi PDII-LIPI, seperti jurnal Internasional tercetak bidang ilmu perpustakaan, dokumentasi, dan informasi. Sebagai rekomendasi, lembaga perlu menetapkan tim seleksi dan tim lelang koleksi untuk melaksanakan kegiatan penataan koleksi (stock opname) dan penyiangan koleksi (weeding) agar dalam proses pelaksanaan kegiatannya berjalan lancar.

\section{DAFTAR PUSTAKA}

Arief, I., \& Handoko. (2017). Jurnal Online Dengan Open Journal System. Padang: Lembaga Pengembangan Teknologi Informasi dan Komunikasi Universitas Andalas 
Bachtar, M. A. (2005). Jejak Langkah Perjalanan PDIN-LIPI 1965-1986. BACA: Jurnal Dokumentasi dan Informasi, Vol. 29, No.1, Juni, 70-89.

Bilandzic, M., \& Foth, M. (2013). Libraries as coworking spaces: Understanding user motivations and perceived barriers to social learning. Library Hi Tech, 31(2). Terdapat pada https://doi.org/10.1108/07378831311329040 (akses 5 Januari 2019).

Gray, J. C. 1972. Scientific and iriformation services in Indonesia: An approach to development in 1974-1979 under the Second Five Year Plan. London: Office of Scientific and Technical Information (Mimeografi).

Kemenristekdikti. (2018). Peraturan Menteri Riset, Teknologi, dan Pendidikan Tinggi RI Nomor 9 Tahun 2018 tentang akreditasi jurnal ilmiah. Jakarta.

Kusmayadi, E. (2008). Akses dan Pemanfaatan Pangkalan Data Jurnal Ilmiah. Jurnal Perpustakaan Pertanian. Vol. 17, No.1.

Lamothe, A. R. (2012). Factors Influencing Usage of an Electronic Journal Collection at a MediumSize University: An Eleven-Year Study. Partnership: Canadian Journal of Library and Information Practice and Research, 7 (1).

Marzuki, R., \& Kohar, A. (1998). Daftar Majalah Ilmiah Luar Negeri Dilanggan PDII-LIPI tahun 1998. Jakarta: PDII-LIPI.

McMillan JH \& Schumacer, S. (2010). Research In Education : Evidence Based Inquiry. New Jersey : Pearson Education Inc.

Moghaddam, G. G., \& Talawar, V. G. (2008). The Use of Scholarly Electronic Journals at the Indian Institute of Science: a Case Study in India, Interlending \& Document Supply, 36 (1),15-29.

Molingka, Y. K., Dewi, D., \& Damayanty. (2014). Pemanfaatan Koleksi Jurnal Tercetak Dalam Memenuhi Kebutuhan Informasi oleh Pemustaka: Studi Deskriptif pada Perpustakaan InstitutTeknologi Bandung. Edulibinfo, Vol 1, No 1.

Murniati, A. (2012). Pemanfaatan E-Journal dan E-Book Oleh Mahasiswa di Lingkungan Fakultas Tarbiyah dan Keguruan Uin Suska Riau. Di http://jurnal.upi.edu/cdid/view/1361/pemanfaatan-e-journal-dan-e-book-oleh-mahasiswadi-lingkungan-fakultas-tarbiyah-dan-keguruan-uin-susk-riau.html.

Nur'aini. (2015). Perbandingan Pemanfaatan Jurnal Tercetak Dengan Jurnal Elektronik untuk Kebutuhan Informasi Mahasiswa Di Perpustakaan Universitas Sumatera Utara Cabang Kedokteran. Berkala Ilmu Perpustakaan dan Informasi, Vol.XI, No.2.

O'Doherty, S., \& Boissy, B. (2009). Is There a Future for the Traditional Subscription-Based Journal?The Serials Librarian, 56:155-162.

PDIN. (1980). Pedoman Kerja PDIN LIPI. Jakarta: PDIN-LIPI.

Permadi, A. (2015). Pedoman Pengembangan Koleksi. Jakarta: PDII-LIPI.

Reitz, J. M. (2014). Online Dictionary for Library and Information Science. Di https://www.abcclio.com/ODLIS/odlis_A.aspx

Sathe, N. A., Grady, J. L., \& Giuse, N. B. (2002). Print versus electronic journals: a preliminary investigation into the effect of journal format on research processes. J Med Libr Assoc. 2002 Apr; 90(2): 235-243.

Sejathi. (2011). Penelitian Evaluatif. SVOONG Books.

Tenopir, C., King, D. W., Edwards, S. \& Wu, L. (2009). Electronic Journals and Changes in Scholarly Article Seeking and Reading Patterns, Aslib Proceedings, 61 (1), 5-32. 